\title{
Revitalisasi Kultur Sekolah dalam Pembangunan Karakter Peserta Didik
}

\author{
Andi Aras \\ Institut Agama Islam Negeri (IAIN) Parepare, Parepare, 91132, Indonesia \\ *email: andi.aras@iainpare.ac.id
}

\begin{abstract}
Abstrak
Salah satu problematika dalam dunia pendidikan adalah degradasi karakter pada peserta didik. Tulisan ini bertujuan untuk mendiskusikan tentang upaya pembangunan karakter peserta didik melalui revitalisasi kultur sekolah. Dalam prakteknya, kultur sekolah sering terabaikan, sehingga terwujud dalam suatu bentuk yang tidak mendukung pembangunan karakter peserta didik. Penelitian ini merupakan library research yang dilaksanakan dengan melakukan kegiatan pengumpulan data pustaka dengan membaca dan mencatat serta mengolah data tersebut. Data-data yang dikumpulkan meliputi data kultur sekolah dan karakter peserta didik. Adapun temuan penelitian ini adalah sekolah yang memiliki kultur yang tidak mendukung pembentukan karakter positif peserta didik perlu diadakan revitalisasi kultur sekolah melalui rekayasa sosial dengan melibatkan semua warga sekolah baik kepala sekolah, guru, maupun staf. Kepala sekolah harus menentukan visi dan misi sekolah, memperhatikan setiap aspek kultur sekolah, menetapkan kebijakan dan aturan yang adil serta memanfaatkan kurikulum sekolah untuk membangun karakter peserta didik. Guru memanfaatkan kegiatan belajar mengajar di kelas untuk membangun karakter peserta didik, menyelipkan pendidikan karakter setiap berinteraksi dengan peserta didik dan memanfaatkan kurikulum tersembunyi untuk menanamkan nilai-nilai moral. Sedangkan staf juga harus terlibat aktif dalam setiap proses pembuatan kebijakan dan aturan serta memastikan bahwa proses pembelajaran akan berjalan lancar dengan merencanakan program-program sekolah beserta anggarannya. Berdasarkan temuan ini, maka kepala sekolah, guru, maupun staf harus memiliki komitmen dalam mewujudkan kultur sekolah yang positif dalam upaya pembentukan karakter peserta didik.
\end{abstract}

Kata Kunci: Revitalisasi, kultur sekolah, karakter peserta didik

\begin{abstract}
One of the problems in the world of education is the degradation of the character of the students. This paper aims to discuss efforts to develop the character of students through revitalizing school culture. In practice, school culture is often neglected, so that it manifests in a form that does not support the character development of students. This research is library research which is carried out by carrying out library data collection activities by reading and recording and processing the data. The data collected includes data on school culture and the character of students. The findings of this study are schools that have a culture that does not support the formation of positive character of students, it is necessary to revitalize
\end{abstract}


school culture through social engineering by involving all school members, both principals, teachers, and staff. The principal must determine the school's vision and mission, pay attention to every aspect of school culture, establish fair policies and rules and utilize the school curriculum to build the character of students. Teachers use teaching and learning activities in the classroom to build the character of students, insert character education every time they interact with students and utilize hidden curriculum to instill moral values. Meanwhile, staff must also be actively involved in every policy and rule-making process and ensure that the learning process will run smoothly by planning school programs and their budgets. Based on these findings, principals, teachers, and staff must be committed to realizing a positive school culture in an effort to build the character of students.

Keywords: Revitalization, school culture, the learner's character

\section{Pendahuluan}

Zaman globalisasi dengan perkembangan IPTEKS yang semakin pesat tidak berbanding lurus dengan perkembangan karakter anak bangsa. Bahkan setiap hari peristiwa di kalangan peserta didik, mahasiswa, masyarakat biasa, hingga pejabat mengalami kemerosotan karakter. Sebagaimana peristiwa peserta didik menganiaya gurunya sendiri yang berujung kematian di SMA Negeri 1 Torju Kabupaten Sampang menjadi sebuah potret hitam yang mencoreng nama baik dunia pendidikan (http://www.tribunnews.com/nasional/2018/02/02).

Tidak bisa dipungkiri bahwa karakter anak bangsa sedang rusak. Namun, bukan berarti tidak memiliki kesempatan untuk menjadi insan yang baik dan berkualitas, dalam artian masih memiliki harapan untuk lebih baik dengan menanamkan nilai-nilai karakter positif. Penanaman nilai-nilai karakter ini dapat dilakukan di lingkungan keluarga, lingkungan sekolah, lingkungan perguruan tinggi, dan lingkungan masyarakat.

Berkaitan dengan hal tersebut, sekolah sebagai lingkungan yang terstruktur dan memiliki orientasi merupakan lingkungan yang memiliki peluang dalam membentuk karakter peserta didik. Selain itu, peserta didik menghabiskan sebagian besar waktunya di sekolah. Di dalam lingkungan sekolah terdapat kultur sekolah yang merupakan gambaran atau karakteristik sekolah yang akan mempengaruhi karakter warga sekolah.

Kultur sekolah positif akan membentuk karakter yang positif dan sebaliknya kultur sekolah negatif akan membentuk karakter warga sekolah yang negatif juga. Namun dalam prakteknya, kultur sekolah merupakan aspek yang kadang diabaikan oleh para warga sekolah. Berbagai penelitian menemukan bahwa sekolah memiliki peluang yang besar dalam merekayasa budaya yang positif dengan memperhatikan berbagai artifak, asumsi, maupun nilai yang dianut para warga sekolah agar dapat terwujud budaya sekolah yang mendukung terwujudnya mutu yang berkualitas (Zahrawati \& Faraz, 2017).

Oleh karena itu, tulisan ini bertujuan untuk mengkaji revitalisasi kultur sekolah dalam pembangunan karakter peserta didik. Berdasarkan hal tersebut, pertanyaan dalam penelitian ini adalah: (1) Bagaimana hubungan kultur sekolah dan karakter? (2) Bagaimana proses revitalisasi kultur sekolah dalam upaya pembangunan karakter peserta didik? Adapun kontribusi dari penelitian ini yaitu dapat menjadi bahan 
pertimbangan ketika kepala sekolah, guru, maupun staf mengambil kebijakan terkait sekolah.

\section{Metode Penelitian}

Penelitian ini merupakan library research dengan melakukan kegiatan pengumpulan data pustaka dengan membaca dan mencatat serta mengolah data tersebut. Data-data yang dikumpulkan meliputi data kultur sekolah dan karakter peserta didik. Adapun sumber data pada penelitian ini tergolong menjadi dua yaitu sumber data primer dan sumber data sekunder. Sumber data primer meliputi karya Deal \& Peterson (2009) tentang Shaping school culture; pitfalls, paradoxes, \& promises second edition dan karya Lickona (2015) tentang Educating for character: how our schools can teach respect and responsibility. Selanjutnya, sumber data sekunder merupakan sumber data pendukung dari isu penelitian ini yaitu revitasisasi kultur sekolah dalam pembangunan karakter peserta didik.

\section{Pembahasan}

\section{Konsep Kultur Sekolah}

Sekolah merupakan institusi sosial yang tidak luput dari pengaruh-pengaruh kebudayaan (Zahrawati \& Faraz, 2017). Sebagai institusional, sekolah mempunyai sistem sosial, organisasi sosial yang unik, termasuk pola interaksi sosial di antara para anggotanya yang disebut kultur sekolah. Kultur sekolah akan menjadi petunjuk bagaimana warga sekolah seharusnya bertindak dan berperilaku. Oleh karena itu, setiap sekolah mempunyai kultur tersendiri yang berbeda dengan kultur sekolah lainnya. Setiap sekolah mempunyai aturan, tata tertib, kebiasaan-kebiasaan, upacara-upacara, mars/hymne sekolah, pakaian seragam, dan lembaga-lembaga yang lain sebagai ciri khas sekolah yang bersangkutan (Padil \& Supriyatno, 2010).

Kultur sekolah memiliki cakupan yang sangat luas, meliputi kegiatan ritual, harapan, hubungan sosial-kultural, aspek demografi, kegiatan kurikuler, kegiatan ekstrakurikuler, proses pengambilan keputusan, kebijakan, maupun interaksi sosial antarkomponen. Kultur sekolah merupakan suasana kehidupan sekolah tempat siswa berinteraksi dengan sesamanya, guru dengan guru, guru/konselor dengan siswa, guru dengan tenaga kependidikan, antara tenaga kependidikan dengan guru dan siswa, dan antar-anggota kelompok masyarakat dengan warga sekolah. Elemen penting kultur sekolah meliputi norma, keyakinan, tradisi, upacara keagamaan, seremoni, dan mitos yang diterjemahkan oleh sekelompok orang tertentu. Kultur sekolah merupakan salah satu aspek yang berpengaruh terhadap perkembangan siswa. Sekolah yang memiliki kultur yang kondusif akan meningkatkan mutu pengelolaan pembelajaran dan pada akhirnya akan menyebabkan prestasi akademik yang tinggi (Wiyani, 2013).

Kultur sekolah merupakan aspek yang patut untuk diperhatikan karena pengaruhnya yang sangat besar terhadap kelangsungan sekolah dan juga kualitas para warganya, sehingga kultur sekolah perlu untuk dipahami secara mendalam. Untuk memperoleh pemahaman yang lebih mendalam, maka sebelumnya akan dibahas mengenai konsep kultur sekolah. Deal \& Peterson (2009) menyatakan bahwa kultur sekolah merupakan jaringan yang kompleks suatu tradisi dan ritual yang dibangun oleh guru, peserta didik, orang tua, dan pimpinan yang bekerja sama dan berhubungan dengan suatu krisis dan pencapaian suatu prestasi. Selanjutnya, kultur yang berada di sekolah akan mempengaruhi perilaku setiap perilaku warga. 
Sedangkan menurut Srinatun (2011), kultur sekolah terdiri dari sejumlah normanorma, ritual, keyakinan, nilai-nilai, sikap, dan kebiasaan yang terbentuk dalam sekolah. Bentuk kultur sekolah pada dasarnya mencerminkan kepercayaan dan keyakinan yang mendalam dan khas dari warga sekolah yang secara intrinsik muncul sebagai suatu fenomena yang unik dan menarik karena pandangan sikap, perilaku yang hidup, dan berkembang dalam sekolah. Adapun aspek-aspek kultur sekolah menurut Brown (1998) terdiri dari artifak, nilai dan perilaku warga sekolah, serta simbil-simbol dan keyakinan para warga sekolah. Artifak sebagai aspek yang pertama dan paling nampak. Aspek ini biasa disebut lingkungan fisik sekolah yang terwujud dalam aneka ragam kebiasaan warga sekolah seperti berbagai upacara dan benda-banda simbolik yang berada di sekolah. Selanjutnya, aspek kedua adalah kepercayaan, nilai, dan perilaku para warga sekolah. Aspek ini terbentuk akibat berbagai kebiasaan-kebiasaan yang dilakukan oleh para warga sekolah. Aspek yang terakhir adalah simbol-simbol dan keyakinan para warga sekolah. Aspek ini terbentuk dari kepercayaan, nilai, dan perilaku warga sekolah. Jadi, dapat disimpulkan bahwa aspek pertama mempengaruhi dan dipengaruhi oleh aspek kedua, begitupun sebaliknya. Aspek kedua mempengaruhi dan dipengaruhi oleh aspek ketiga, begitupun sebaliknya. Keyakinan para warga sekolah tergantung pada kepercayaan, nilai, dan perilaku warga sekolah. Selanjutnya, kepercayaan, nilai, dan perilaku warga sekolah tergantung pada artefak atau lingkungan fisik sekolah tersebut yang biasa terwujud dalam kebiasaan-kebiasaan dan benda-benda simbolik yang berada di sekolah.

Seperti halnya kultur di masyarakat, kultur di sekolah memiliki sifat dan hakikat yang dapat dilihat dan dirasakan dalam kehidupan sehari-hari oleh warganya. Adapun sifat-sifatnya, yaitu: (a) diperoleh dari belajar, kultur diperoleh melalui proses sosialisasi dan internalisasi, yakni dengan cara berinteraksi dengan manusia lain dalam suatu kelompok, (b) milik bersama, kultur merupakan milik bersama, sehingga semua anggota harus mematuhinya dan mengikutinya karena diikat oleh konvensi, nilai-nilai, dan norma atau bahkan aturan, (c) kultur merupakan pola, pola-pola seperti pola tingkah laku dan lain sebagainya terjadi karena dalam kebudayaan ada nilai atau batasanbatasan yang mengatur cara hidup dan tingkah laku. Pola yang ideal adalah apa yang secara nilai diakui bersama oleh para anggotanya. Pola-pola inilah yang sering disebut norma, dan (d) bersifat dinamis dan adaptif, kultur dapat berubah baik secara pelan maupun cepat, tergantung pada perubahan material yang dihadapi (Soyomukti, 2013).

Dari berbagai pemaparan tersebut, maka dapat disimpulkan bahwa kultur sekolah merupakan karakteristik suatu sekolah yang merepresentasikan keadaan sekolah tersebut meliputi kepercayaan, norma-norma, nilai-nilai, tradisi, dan sikap beserta tingkah laku warga sekolah baik peserta didik, kepala sekolah, guru, karyawan.

\section{Konsep Karakter}

Karakter merupakan nilai-nilai perilaku manusia yang universal yang meliputi seluruh aktivitas manusia, baik dalam rangka berhubungan dengan Tuhannya, dengan dirinya, dengan sesama manusia, maupun dengan lingkungannya yang terwujud dalam pikiran, perasaan, dan perkataan serta perilaku sehari-hari berdasarkan norma agama, hukum, tata krama, budaya, dan adat istiadat (Zuchdi et al, 2015).

Sejalan dengan pendapat Lickona (2015) yang menyatakan bahwa karakter merupakan sesuatu yang bernilai operatif dan memiliki tiga bagian yang saling berhubungan, yakni: (1) pengetahuan moral terdiri dari kesadaran moral, pengetahuan 
nilai moral, penentuan perspektif, pemikiran moral, pengambilan keputusan, dan pengetahuan pribadi; (2) perasaan moral terdiri dari hati nurani, harga diri, empati, mencintai hal yang baik, kendali diri, dan kerendahan hati; (3) perilaku moral atau tindakan moral terdiri dari kompetensi, keinginan, dan kebiasaan.

Begitupun Naim (2012) mendefinisikan karakter tidak jauh berbeda bahwa karakter mengacu kepada serangkaian sikap (attitudes), perilaku (behaviors), motivasi (motivations), dan keterampilan (skills). Sikap yang mengarah kepada perilaku-perilaku yang mengandung kebaikan seperti jujur dan bertanggung jawab serta kecakapan interpersonal dan emosional merupakan interpretasi dari karakter yang baik. Dengan demikian dapat disimpulkan bahwa karakter adalah nilai-nilai yang tercermin pada sikap dan perilaku seseorang yang merupakan hasil dari proses pengetahuan dan penghayatan terhadap moral.

\section{Kultur Sekolah dan Karakter Peserta Didik}

Kultur sekolah mempengaruhi setiap anggota dalam organisasi sekolah karena kultur sekolah merupakan kekuatan pendorong untuk semua kegiatan di sekolah dengan menyatukan warga sekolah, memberikan pemahaman yang mendalam untuk fokus pada tujuan yang ingin dicapai (Karuppiah et al, 2014). Kultur sekolah yang positif akan mendorong semua warga sekolah untuk bekerjasama yang didasarkan saling percaya, mengundang partisipasi seluruh warga, mendorong munculnya gagasan-gagasan baru, dan memberikan kesempatan untuk terlaksananya pembaruan di sekolah yang semuanya ini bermuara pada pencapaian hasil terbaik. Iklim yang mendorong semua warga sekolah untuk belajar dan bekerjasama hanya dapat ditumbuhkan melalui kultur sekolah yang positif. Melalui kultur sekolah positif juga akan tumbuh suatu iklim belajar yang menyenangkan. Para peserta didik akan menganggap belajar adalah sebuah kebutuhan bukan keterpaksaan karena belajar mucul dari dorongan diri sendiri bukan karena tekanan dari luar dalam segala bentuknya (Kurniawan, 2014).

Lantas bagaimana sesuatu yang berada diluar diri seseorang seperti kultur sekolah dapat menjadi pembangun karakter peserta didik? Berkaitan dengan pertanyaan tersebut, maka teori social fact dari Emile Durkheim menjadi gambaran bagaimana sesuatu yang berada di luar diri seseorang dapat mempengaruhi diri seseorang tersebut. Berhubungan dengan karakteristik fakta sosial, Durkheim, (1982) menyatakan bahwa:

A social fact is identifiable through the power of external coercion which it exerts or is capable of exerting upon individuals. The presence of this power is in turn recognizable because of the existence of some predetermined sanction, or through the resistance that the fact opposes to any individual action that may threaten it. However, it can also be defined by ascertaining how widespread it is within the group, provided that,...., one is careful to add a second essential characteristic; this is, that it exists independently of the particular forms that it may assume in the process of spreading itself within the group.

Dari pernyataan tersebut, dapat diartikan bahwa sebuah fakta sosial dapat diidentifikasi melalui kekuatan paksaan eksternal yang diberikannya atau mampu mengerahkan individu. Kehadiran kekuatan ini pada gilirannya dikenali karena adanya beberapa sanksi yang telah ditentukan, atau melalui perlawanan yang menentang fakta untuk setiap aksi individu yang dapat mengancam itu. Namun, juga dapat didefinisikan dengan memastikan seberapa luas itu dalam kelompok, asalkan, salah satu adalah 
berhati-hati untuk menambahkan karakteristik penting kedua; ini, bahwa itu ada secara independen dari bentuk-bentuk tertentu yang mungkin menganggap dalam proses penyebaran itu sendiri dalam kelompok. Dengan demikian dapat dikatakan bahwa sebuah fakta sosial memiliki karakteristik yaitu bersifat eksternal, memaksa, dan umum (general).

Demikian halnya kultur sekolah, meskipun berada di luar diri seseorang tetapi dapat memaksa seseorang dalam berperilaku karena selain bersifat umum dalam artian berlaku untuk seluruh warga yang berada di sekolah, juga memiliki kekuatan karena adanya sanksi sebagai langkah preventif. Oleh karena itu, perlunya pengembangan kultur sekolah yang positif karena berbagai permasalahan yang dihadapi sekolah dapat teratasi jika setiap sekolah memiliki kultur yang positif sebagai pegangan dalam mengambil tindakan.

\section{Revitalisasi Kultur Sekolah}

Kultur sekolah terwujud dalam nilai-nilai, keyakinan, norma-norma, cerita, upacara, simbol sekolah, termasuk pola interaksi sosial di antara para anggotanya. Kultur sekolah menjadi sebuah acuan dalam bertindak dan berinteraksi antar sesama warga sekolah, sehingga secara langsung kultur sekolah dapat memberikan dampak pada kualitas sebuah sekolah. Selain itu, kultur sekolah merupakan sumber utama dari keunggulan kompetitif suatu sekolah. Peran kultur sekolah yang sangat penting ini menjadi tanggung jawab semua warga sekolah untuk ikut berpartisipasi aktif dalam mengembangkan kultur sekolah yang positif.

Pentingnya revitalisasi kultur sekolah karena kultur sekolah memiliki pengaruh/konsekuensi terhadap seluruh warga sekolah terutama guru dan peserta didik. Konsekuensi pada diri guru meliputi: orientasi tujuan, keefektifan diri, usaha, kegigihan, dan kepuasan. Sedangkan konsekuensi pada diri peserta didik meliputi: orientasi tujuan, keefektifan diri, usaha, kegigihan, dan prestasi (Schunck et al, 2012).

Sekolah sebagai sebuah organisasi sangat memerlukan kultur positif agar dapat menjadi pegangan dalam melaksanakan kegiatan di sekolah dan menjadi pedoman dalam menghadapi segala permasalahan-permasalahan yang dihadapi oleh warga sekolah. Sebab, sekolah harus memiliki kemampuan untuk hidup, tumbuh berkembang, dan melakukan adaptasi dengan berbagai lingkungan yang ada agar terciptanya integrasi internal (Zamroni, 2007).

Pengembangan kultur sekolah melalui rekayasa sosial sangat diperlukan karena kultur sekolah yang bertumbuh secara alami belum tentu akan bermuara pada kultur sekolah yang positif. Para warga sekolah perlu menentukan visi dan misi sekolah secara jelas. Kemudian memberikan pertimbangan-pertimbangan cara yang dapat dilalui untuk mencapai tujuan tersebut. Salah satu bentuk rekayasa sosial untuk mengembangkan kultur sekolah adalah implementasi pengembangan kultur sekolah dengan mendesain kebijakan, strategi, dan model pengembangan kultur sekolah (Zamroni, 2011).

Selain itu, untuk dapat mengembangkan kultur sekolah pertama-tama harus memahami kultur yang ada. Pengembangan kultur yang ada dimaknai sebagai alternatif variasi interaksi yang seluas-luasnya karena interaksi ini dapat dikatakan sebagai inti 
dari stabilitas sekolah, pembaruan harus didekati melalui dialog peduli kepada orang lain, dan lain-lain. Kultur yang telah rutin dimiliki oleh komunitas sekolah misalnya seremonial, ritual, tradisi, mitos dapat digunakan sebagai titik tolok pembaruan kultur sekolah. Pada prinsipnya upaya memperpendek waktu antara penerapan sistem interaksi baru dengan kultur yang konvensional dilakukan bila guru telah merasa kondusif diterapkan sistem interaksi yang baru itu, sehingga sekolah memperolah nilai yang dikehendaki (Srinatun, 2011).

Selanjutnya, sikap terbuka dan senantiasa mau belajar dari pengalaman merupakan hal yang mutlak bagi pengembangan sebuah kultur sekolah. Kultur sekolah yang mendukung pembangunan karakter dapat terwujud apabila dalam perancangan sebuah program sekolah, seluruh warga sekolah berpartisipasi aktif dalam merealisasikan visi dan misi yang telah ditetapkan melalui kegiatan-kegiatan yang membentuk dasar bagi pertumbuhan kultur sekolah yang sehat dan dewasa. Programprogram itupun perlu direncanakan, didesain, dan dievaluasi secara terus-menerus (Koesoema, 2016).

Jadi, kultur sekolah dapat menjadi pegangan bagi setiap warga sekolah. Kultur yang berada di sekolah sangat berperan dalam menghadapi berbagai masalah yang berada di sekolah. Kultur sekolah akan menjadi pedoman warganya dalam berperilaku termasuk dalam menyelesaikan permasalahan-permasalahan yang dihadapi. Lantas seperti apa langkah dalam pengembangan kultur sekolah yang mendukung pembentukan karakter peserta didik?

Sebelumnya, dalam upaya pengembangan kultur sekolah harus memperhatikan beberapa prinsip yakni: pertama, menyampaikan informasi yang rasional mengenai konsekuensi yang diperoleh jika melaksanakan tindakan yang diberitahukan tersebut. Kedua, para warga sekolah membuat kebijakan atau peraturan untuk ditaati oleh semua pihak. Ketiga, mensosialisasikan kepada seluruh warga sekolah akan isi dan target pengembangan kultur sekolah. Dan terakhir, diperlukan role model sebagai teladan dan contoh konkret bagi para warga sekolah terkhusus peserta didik (Zamroni, 2011).

Pengembangan kultur sekolah membutuhkan keterlibatan semua warga sekolah baik kepala sekolah, guru, staf maupun peserta didik. Kepala sekolah merupakan sosok penting dalam sebuah organisasi sekolah (Zahrawati \& Ramadani, 2021). Walaupun dalam proses pengambilan kebijakan secara demokratis dan melibatkan seluruh warga sekolah. Namun, lagi-lagi kepala sekolah lah yang menjadi penengah dan pengambil kebijakan. Sebagaimana Zamroni (2011) menyatakan bahwa kepala sekolah memegang peran penentu akan wajah kultur sekolah. Oleh karena itu, dibutuhkan sosok kepala sekolah yang memiliki nilai-nilai, keyakinan, pandangan, sikap, dan perilaku yang positif dengan jalan membuat peraturan dan kebijakan sekolah yang mengantarkan sekolah tersebut menuju peningkatan mutu sekolah.

Dalam kaitannya dengan pengembangan kultur sekolah yang positif, kepala sekolah harus mampu menentukan visi dan misi sekolah, memperhatikan setiap aspek kultur sekolah agar mengarahkan kepada pembangunan karakter peserta didik. Misalnya, pada aspek artifak: kepala sekolah membuat program-program kegiatan sekolah yang mengarah pada pembangunan karakter peserta didik, membiasakan pelaksanaan upacara, memajang benda-benda simbolik seperti gambar Pancasila, pahlawan-pahlawan, dan lain sebagainya untuk menumbuhkan sikap nasionalisme 
peserta didik. Selain itu, kepala sekolah hendaknya menetapkan kebijakan dan aturan yang adil serta memanfaatkan kurikulum sekolah untuk membangun karakter peserta didik.

Di sisi lain, guru sebagai ujung tombak dalam pendidikan dapat mamanfaatkan kegiatan belajar mengajar di kelas untuk membangun karakter peserta didik, menyelipkan pendidikan karakter setiap berinteraksi dengan peserta didik dan memanfaatkan kurikulum tersembunyi untuk menanamkan nilai-nilai moral. Sedangkan staf juga harus terlibat aktif dalam setiap proses pembuatan kebijakan dan aturan serta memastikan bahwa proses pembelajaran akan berjalan lancar dengan merencanakan program-program sekolah beserta anggarannya.

\section{Kesimpulan}

Kultur sekolah merupakan karakteristik suatu sekolah yang merepresentasikan keadaan sekolah tersebut meliputi kepercayaan, norma-norma, nilai-nilai, tradisi, dan sikap beserta tingkah laku warga sekolah baik peserta didik, kepala sekolah, guru, karyawan. Sebagai karakteristik suatu sekolah, kultur sekolah mempengaruhi pembangunan karakter semua warga sekolah termasuk peserta didik. Peran kultur sekolah yang sangat besar ini, maka diperlukan revitalisasi kultur sekolah melalui pengembangan kultur sekolah. Pengembangan kultur sekolah secara alamiah tidak menjamin akan menghasilkan kultur sekolah positif yang mendukung pembangunan karakter peserta didik. Oleh karena itu, diperlukan rekayasa sosial dalam upaya pengembangan kultur sekolah. Untuk dapat mengembangkan kultur sekolah yang positif, pertama-tama harus memahami kultur sekolah yang ada. Kemudian melakukan implementasi pengembangan kultur sekolah dengan mendesain kebijakan, strategi, dan model pengembangan kultur sekolah. Namun dalam hal ini, diperlukan sikap terbuka dan senantiasa mau belajar dari pengalaman. Berkaitan dengan langkah yang harus ditempuh, tentunya semua warga sekolah harus terlibat aktif dalam pengembangan kultur sekolah. Kepala sekolah harus mampu menentukan visi dan misi sekolah, memperhatikan setiap aspek kultur sekolah agar mengarahkan kepada pembangunan karakter peserta didik. Selain itu, kepala sekolah hendaknya menetapkan kebijakan dan aturan yang adil serta memanfaatkan kurikulum sekolah untuk membangun karakter peserta didik. Di sisi lain, guru sebagai ujung tombak dalam pendidikan dapat mamanfaatkan kegiatan belajar mengajar di kelas untuk membangun karakter peserta didik, menyelipkan pendidikan karakter setiap berinteraksi dengan peserta didik dan memanfaatkan kurikulum tersembunyi untuk menanamkan nilai-nilai moral. Sedangkan staf juga harus terlibat aktif dalam setiap proses pembuatan kebijakan dan aturan serta memastikan bahwa proses pembelajaran akan berjalan lancar dengan merencanakan program-program sekolah beserta anggarannya. Adapun keterbatasan penelitian ini adalah ketidakmampuan untuk menggambarkan secara keseluruhan terkait kultur sekolah dan pembangunan karakter peserta didik dikarenakan metode yang digunakan adalah library research. Oleh karena itu, disarankan untuk penelitian selanjutnya dapat menggunakan metode kualitatif ataupun kuantitatif. 


\section{Referensi}

Brown, A. (1998). Organisational culture 2nd edition. New York: Pearson Education, Inc.

Deal, T. E., \& Peterson, K. D. (2009). Shaping school culture; pitfalls, paradoxes, \& promises second edition. New Jersey: John Wiley \& Sons, Inc.

Durkheim, E. (1982). The Rules of Sociological Method. New York: The Free Press.

Karuppiah, C. a/p, Fooi, F. S., Hamid, J. A., \& Samah, B. A. (2014). Transformational Leadership, School Culture and Risk Management Practices at Elementary Schools in Malaysia. Middle-East Journal of Scientific Research, 19, 39-46. https://doi.org/10.5829/idosi.mejsr.2014.19.icmrp.7

Koesoema, D. A. (2016). Pendidikan Karakter Utuh dan Menyeluruh (16th ed.). Yogyakarta: Kanisius.

Kurniawan, S. (2014). Pendidikan Karakter: Konsepsi dan Implementasinya Secara Terpadu di Lingkungan Keluarga, Sekolah, Perguruan Tinggi, dan Masyarakat. Yogyakarta: Ar-Ruzz Media.

Lickona, T. (2015). Educating for Character: How Our Schools Can Teach Respect and Responsibility, diterjemahkan oleh Juma Abdu Wamaungo dengan judul, Education for Character; Mendidik untuk Membentuk Karakter Bagaimana Sekolah dapat Mengajarkan Sikap Hormat dan Tanggung Jaw. Jakarta: PT. Bumi Aksara.

Naim, N. (2012). Character Building. Yogyakarta: Ar-Ruzz Media.

Padil, M., \& Supriyatno, T. (2010). Sosiologi Pendidikan. Malang: UIN-Maliki Press.

Schunck, Pintrich, \& Meece. (2012). Motivasi dalam Pendidikan; Teori, Penelitian, dan Aplikasi Edisi Ketiga. (Terjemahan Ellys Tjo). New York: Pearson Education, Inc.

Soyomukti, N. (2013). Pengantar sosiologi; dasar analisis, teori, \& pendekatan menuju analisis masalah-masalah sosial, perubahan sosial, \& kajian-kajian strategis. Yogyakarta: Ar-Ruzz Media.

Srinatun. (2011). Upaya Meningkatkan Kinerja Guru melalui Kultur Sekolah. Integralistik, (1).

Wiyani, N. A. (2013). Membumikan pendidikan karakter di SD; konsep, praktik, \& strategi. Yogyakarta: Ar-Ruzz Media.

Zahrawati, F., \& Faraz, N. J. (2017). Pengaruh kultur sekolah, konsep diri, dan status sosial ekonomi orang tua terhadap perilaku konsumtif siswa. Harmoni Sosial: Jurnal Pendidikan IPS, 4(2), 131-141.

Zahrawati, F., \& Ramadani, A. N. (2021). Problematika implementasi kurikulum 2013 terhadap proses pembelajaran pada masa pandemik COVID-19. Bidayatuna: Jurnal Pendidikan Guru Madrasah Ibtidaiyah, 04(01), 59-74.

Zamroni. (2007). Pendidikan dan demokrasi dalam transisi (prakondisi menuju era globalisasi). Jakarta: PSAP Muhammadiyah.

Zamroni. (2011). Dinamika peningkatan mutu. Yogyakarta: Gavin Kalam Utama.

Zuchdi et al. (2015). Pendidikan Karakter: Konsep Dasar dan Implementasi di Perguruan Tinggi. Yogyakarta: UNY Press. 